\title{
Attitudes towards money and motivational orientation to work in Brazilian young workers
}

Danielli Leite Campos

\section{Monteiro}

Universidade Estadual do Ceará danieli.campos@uece.br

\section{Verónica Peñaloza}

Universidade Estadual do Ceará veronica.penaloza@uece.br

Francisco Roberto Pinto Universidade Estadual do Ceará roberto.pinto@uece.br

\section{Marianela del Carmen}

Denegri Coria

Universidad de La Frontera marianela.denegri@ufrontera.cl

\section{Ligia María Orellana} Calderón

Universidad de La Frontera lm.orca@gmail.com

\begin{abstract}
Self-determination theory assumes that there are two motivational orientations: intrinsic and extrinsic motivation. Money is a means to different ends, thus considered an external source of motivation, but individuals may also attribute other meanings to it. The aim of this research was to study the relationship between motivational orientation and the attitude towards money in young employees in Brazil. The sample consisted of 163 young workers attending a Business Administration program at a public university in Fortaleza, Brazil. The Work Preference Inventory (WPI), the Love of Money Scale (LOMS) and a socio-demographic questionnaire were applied. The data was examined using descriptive statistics, correlations, factor analysis and cluster analysis and comparisons. The individuals' motivational orientation to work was found to be associated with their attitude towards money. Two profiles were identified, based on their differences between source of motivation and perception of money as a reward and as evil. Identifying the profiles that connect motivation with meaning of money may allow organizations to design and implement compensation systems according to their employees' needs.
\end{abstract}

Keywords: motivational orientation, extrinsic motivation, intrinsic motivation, money, young workers 


\section{Actitudes hacia el dinero y orientación motivacional hacia el trabajo en jóve- nes trabajadores brasileños}

\section{Resumen}

La teoría de la autodeterminación asume la existencia de dos tipos de orientación motivacional: motivación intrínseca y extrínseca. El dinero es un medio para lograr diferentes fines y, por tanto, se considera fuente externa de motivación, pero las personas también pueden atribuirle otros significados. El objetivo de esta investigación fue indagar la relación entre orientación motivacional y la actitud hacia el dinero en jóvenes empleados en Brasil. La muestra fue de 163 trabajadores jóvenes que cursaban la carrera de Administración de Empresas en una universidad pública en Fortaleza, Brasil. Los cuestionarios aplicados fueron el Work Preference Inventory (WPI), Love of Money Scale (LOMS) y otro de variables sociodemográficas. Los datos fueron analizados a través de correlaciones, análisis factorial y análisis y comparación de clúster. Se encontró que la orientación motivacional de los individuos hacia el trabajo estaba asociada con su actitud hacia el dinero. Se identificaron dos perfiles, basándose en las diferencias entre la fuente de motivación y la percepción del dinero como recompensa o como vil. El identificar los perfiles que conectan la motivación con el significado del dinero permitirá a las organizaciones diseñar e implementar sistemas de compensación acordes a las necesidades de sus empleados.

Palabras clave: orientación motivacional, motivación extrínseca, motivación intrínseca, dinero, trabajadores jóvenes

\section{Introduction}

Motivation is a fundamental issue in psychology, both in terms of biological drives and social influence. In the corporate scenario, where interest is directed towards improving the performance of employees to achieve the goals of the organization, motivation remains a major challenge given the coexistence of diverse interests and distinct motivations (Bergamini, 1990) How to move individuals to consistently take action within a complex and diverse environment is one of the topics of interest to organizations.

According to Deci and Ryan (1985), psychological motivational theories seek to identify the direction and power of human behavior. Several theorists have studied motivation (Deci \& Ryan, 1985; Maslow, 1970; Ryan \& Deci, 2000a; Skinner, 1953/2003; Vroom, 1970) and although they do not differ about the object of research, their studies originate from different influences. The field of motivation is 
a vast and complex theoretical tangle, and its ideas can be guided by behaviorist, cognitive and humanistic psychoanalytic principles (Penna, 2001).

As part of this wide theoretical ground, the Self-Determination Theory (SDT) is a macro-theory of human motivation, personality development and wellbeing, developed by Edward L. Deci and Richard M. Ryan in the 1970s (Deci and Ryan, 1985a), and research continues to the present time (Ryan \& Deci, 2000a, 2000b). The hypothesis that humans are organisms instead of mechanisms represents the starting point of the humanist vision adopted in the study of SDT. According to the authors, the objective of research on SDT is to clarify the organic and humanistic hypothesis behind motivation using empirical methods. Two main traditions of psychology are the foundation of the SDT: the assessment of people as organisms by the psychoanalytic tradition, and the use of empirical research methods. Therefore, the SDT can be described as a humanist- empirical one (Deci, 1998).

Most motivational theories conceive motivation as a unitary phenomenon that can be measured in degrees (Ryan \& Deci, 2000a): a person who does not feel driven to act is considered unmotivated; a person who feels inspired to act for a particular purpose is considered to be motivated. However, people's motivation does not differ only in amount - poorly or very motivated - but also in orientation, which is based on reasons or goals that cause action (Deci \& Ryan, 1985). Consequently, the SDT focuses on the interaction among extrinsic forces acting upon people, the individual's own intrinsic forces and basic human needs of competence, autonomy and relatedness (Dysvik \& Kuvaas, 2012; McCally, 2010; Ryan \& Deci, 2000b).

In this regard, some authors (Amabile et al., 1994; Ebert, 2010; Dysvik \& Kuuvas, 2012; Deci \& Ryan, 2000) have defined types of motivational orientations. Some people seem driven in their work by passion, they find their tasks enjoyable and their involvement and participation are their own reward. This is an autonomous motivation, better known as intrinsic motivation (IM). On the other hand, there are people who seem more motivated by external incentives, their activities are conducted in order to attain a desired consequence or to avoid punishment; this is extrinsic motivation (EM). IM is based on volition and choice while EM is instrumental, based on pressure to act and respond to potential environmental consequences resulting from the performance (Deci \& Ryan, 1985; Dysvik \& Kuuvas, 2012). Research suggests that motivational orientations can be, aside from a result from social consequences, a relatively stable individual difference (Amabile, 1985; Amabile et al., 1994). 
In order to evaluate both motivational orientations in labor and school contexts, Amabile and colleagues (1994) developed the Work Preference Inventory (WPI). Two versions of this instrument were developed, varying in five items that assess compensation: working adults receive wage and promotions, while students are rewarded with good grades and accolades. The remaining items measure factors that are comparable between both populations. Ultimately, the WPI was conceived as an assessment of individual differences in terms of whether people consider themselves intrinsically or extrinsically motivated to carry out their activities. It has been established that IM and EM have a distinct influence on employees' outcomes (Gagné \& Deci, 2005). While there is a positive relationship between extrinsic motivators and effort at work (Dysvik \& Kuvaas, 2012), it has also been found that people with high IM at the workplace have greater motivation and tend to need less supervision (Pascual, Prelec \& Dunfield, 2013).

Money-based rewards are considered powerful motivators (Furnham, 1996; Luna \& Tang, 2004; Medina, Gallegos \& Lara, 2008; Tang, 1992, 1993, 1995, 2007, 2010; Tang, Kim \& Tang, 2000). Money increasingly acquires value as a result of its perceived instrumentality to access other desired results (Lea \& Webley, 2006; Vroom, 1970). The meaning of money depends on the individual but money itself is an objective means to obtaining goods and fulfilling needs and desires, so it is indispensable and it influences several aspects of modern life. Tang (1992) indicated that social values are related to money matters and argued that in a materialistic society, people are highly driven by money and see money as a source of power and happiness.

Researchers have examined the attitudes towards money, seeking to define the cognitive structure of this construct and the variables related to it (Moreira, 2002), as well as its relation to motivation, satisfaction and job performance (Medina, Gallegos \& Lara, 2008; Tang, Kim \& Tang, 2000). Considering money as an individual difference attribute can have a significant impact in the design and implementation of organizational compensation systems (Lim, 2003).

In order to measure this construct, Luna-Arocas and Tang (2004) developed the Love of Money Scale (LOMS), which has been tested in several cultures, languages and religions (e.g. Wong, 2008). The LOMS was originally applied to Spanish and American university professors to examine their relation to money and their intrinsic and extrinsic work satisfaction. Five factors originated using exploratory factor analysis: Budget, Success, Motivator, Equity and Evil. Using these factors, 
the authors performed a cluster analysis and identified four profiles of professors in relation to money: Achieving Money Worshippers, Careless Money Admirers, Apathetic Money Managers and Money Repellent Individuals.

The Apathetic Money Managers were more intrinsically satisfied, had internal locus of control, were more self-determined and therefore did not do activities for the money but the satisfaction that they provided. The Achieving Money Worshippers considered money a symbol of success and status, and they also managed their money carefully. Thereby, they were more motivated by money than the other groups and best performed within a system of rewards for job performance.

Individuals classified as Careless Money Admirers were extrinsically satisfied, had external locus of control and were less self-determined. Individuals in this group were concerned with extrinsic rewards which lead to less intrinsic satisfaction. Money is an important motivator for these individuals and there was a possible implication, highlighted by more recent studies (Kouchakia et al., 2013; Pascual et al., 2013; Wong, 2008), that these individuals may be tempted to engage in unethical behavior inside their organizations. Finally, the Money Repellent Individuals presented more negative attitudes towards money. Individuals in this group characterized money as evil, they considered it was not a reflection of success and it did not function as reinforcement for them. Considering these four profiles, organizations ought to establish different strategies in order to motivate their employees as a whole and individually (Medina, Gallegos \& Lara, 2008).

Despite the significant progress in motivational research, the intrinsic and extrinsic motivational orientations in organizational environments need to be further studied, mainly in geographical areas most deprived of attention, as is the case of Brazil. The knowledge of the motivational profile of employees and the meaning that they personally attach to money is strategically interesting because it enables organizations to plan the direction of their motivational support efforts.

Consequently, this study aims to answer the following question: what is the relationship between the attitude towards money and the motivational orientation to work? To answer this question, the general objective of this research is to differentiate young workers attending a Business Administration program at a public university in Fortaleza, Brazil, by their attitude towards money and their motivational orientation. To achieve this objective, the following hypotheses are proposed: 
$H_{1}$. Individuals driven by money will display extrinsic motivational orientation.

$\mathrm{H}_{2}$. Individuals opposed to money will display intrinsic motivational orientation.

\section{Method}

\section{Participants and procedure}

A convenience non-probabilistic sample was considered, applying 180 questionnaires to young people who had a daytime job and attended night school. 17 subjects were excluded on account of being unemployed. Thus the final sample consisted of 163 young employees attending a Business Administration program in a public university of Fortaleza, Brazil. 58.9\% of the participants were male and $41.1 \%$ female, ranging in age from 18 to 35 years with a mean age of 22.7 years $(\mathrm{ED}=2.1) .90 .7 \%$ were single and $9.3 \%$ married, and five people from the latter group declared to have children.

Once ethical clearance for the study was obtained, the questionnaires were applied during April 2011, in compulsory Business Administration courses at the public university, by a trained researcher who provided the instructions. Participants remained anonymous and spent on average 20 minutes filling out the questionnaire.

Due to the complete randomness of missing cases, the non-responses to certain questionnaire items - missing values - were excluded for the factor analysis using list-wise deletion. Another tested assumption was the absence of outliers, i.e., a response deviating from the standard of other observations in the sample. Thus, no questionnaire was discarded due to outliers or missing values.

\section{Instruments}

The questionnaire was divided in three sections. The first one was the 30 item Work Preference Inventory (Amabile et al., 1994). The second section was the 15 item Love of Money Scale (Luna and Tang, 2004). The last section enquired about socio-demographic variables such as gender, age and marital status.

Initially, the 30 WPI items were translated from English to Portuguese by an expert in English language, based on a previous translation made by Guimarães and Bzuneck (2002). Although these authors have applied the WPI to students following Amabile et al. (1994), this scale differs in five items which assess compensation 
in the workplace. The 15 LOMS items (Luna-Arocas and Tang, 2004) were also translated by experts in English language, in conjoint work with the researchers.

The four-point Likert-type scale for the WPI was the one used by Amabile et al. (1994). For the LOMS, the same Likert-type scale was adopted to maintain the questionnaire format, although this differs from the original scale used by Luna-Arocas and Tang (2004). Therefore, for the 30 WPI items, 1 corresponds to "it is never true for me" and 4 corresponds to "it is always true for me." In the LOMS, 1 corresponds to "I strongly disagree" and 4 to "I strongly agree".

An Factor Analysis (EFA) was conducted to identify representative factors from the WPI and the LOMS. For both scales, the following criteria were adopted: communality was extracted from items higher than 0.4; Bartlett's Sphericity Test was significant at 5\%; the Kaiser-Meyer-Olkin (KMO) test should be superior to 0.6. To estimate factor loadings, the principal components method was used, and in order to determine the number of factors, greater-than-one values criterion was used. For both scales, the normalized varimax rotation method was used, as recommended by Hair et al. (2005).

\section{Results}

\section{Factor analysis}

For the motivational orientation scales, the Kaiser-Meyer-Olkin (KMO) and Bartlett's Test of Sphericity were examined first to test the adequacy of the factor analysis. As shown on table 1, MSA scores were 0.645 and 0.622 and Bartlett's Sphericity was significant, considering the appropriate data for the factor analysis.

Table 1

\section{KMO and Bartlett's Test for WPI and LOMS}

\begin{tabular}{c|l|l|l}
\hline \multirow{3}{*}{ WPI } & \multicolumn{2}{|l|}{ Kaiser-Meyer-Olkin Measure of Sampling Adequacy } & .645 \\
\cline { 2 - 4 } & Bartlett's Test of Sphericity & Aprox. Chi-Square & 641.391 \\
& & Df & 90 \\
& & Sig. & .000 \\
\hline \multirow{4}{*}{ LOMS } & \multicolumn{2}{|l|}{ Kaiser-Meyer-Olkin Measure of Sampling Adequacy } & .622 \\
\cline { 2 - 4 } & Bartlett's Test of Sphericity & Aprox. Chi-Square & 338.025 \\
& & Df & 66 \\
& & Sig. & .000 \\
\hline
\end{tabular}


The EFA conducted for the WPI grouped the items into two factors (table 2) and explained $40.75 \%$ of the total variance: $22.36 \%$ corresponded to the first factor, Intrinsic Motivation (IM), and $18.39 \%$ corresponded to the second factor, Extrinsic Motivation (EM). Following the procedures performed by Amabile et al. (1994), bi-dimensionality was forced by setting a two-factor extraction. As argued by these authors, although IM and EM may have similarities in their various components, data suggest that the two are distinct constructs. Eight items from each factor were excluded due to low communality.

The reliability of the IM and EM scales was tested using Cronbach's alpha, and the values obtained were 0.71 for IM and 0.65 for EM. The values obtained by Amabile (1994) were 0.79 and 0.78 respectively. According to Kline (1999, cited in Field, 2009), these are acceptable values, since results below 0.7 can be expected from psychological constructs due to the diversity of constructs measured.

Table 2

WPI items grouped after Factor Analysis

\begin{tabular}{|c|c|c|c|}
\hline \multirow{2}{*}{\multicolumn{2}{|c|}{ Variables }} & \multicolumn{2}{|c|}{ Factors } \\
\hline & & \multirow{2}{*}{$\begin{array}{l}\begin{array}{c}\text { Intrinsic } \\
\text { motivation }\end{array} \\
0.720\end{array}$} & $\begin{array}{l}\text { Extrinsic } \\
\text { motivation }\end{array}$ \\
\hline 1. & I like trying to solve complex problems. & & \\
\hline 2. & I like to deal with problems that are completely new to me. & 0.679 & \\
\hline 3. & I want to find out how much I can be really good at my work. & 0.677 & \\
\hline 4. & The harder the problem is, the more I like trying to solve it. & 0.664 & \\
\hline 5. & $\begin{array}{l}\text { I want my work to provide me opportunities to increase my } \\
\text { knowledge and skills. }\end{array}$ & 0.644 & \\
\hline 6. & It is important for me to be able to do what I like the most. & 0.575 & \\
\hline 7. & For me, the important thing is to like what I do. & 0.470 & \\
\hline 8. & I am highly motivated by the money I can earn. & & 0.709 \\
\hline 9. & I have to feel that I am gaining something for what I do. & & 0.692 \\
\hline 10 . & I rarely think about salary and promotion.(r) & & 0.591 \\
\hline 11. & $\begin{array}{l}\text { Provided I can do what I like, I am not so worried about } \\
\text { exactly how much I earn for it.(r) }\end{array}$ & & 0.566 \\
\hline 12. & $\begin{array}{l}\text { I want other people find out how much I can be really good } \\
\text { at my work. }\end{array}$ & & 0.504 \\
\hline 13. & I am highly motivated by the recognition I get from others. & & 0.481 \\
\hline \multirow[t]{3}{*}{14.} & My wage goals are clear to me. & & 0.416 \\
\hline & Variance explained by factors & $22.36 \%$ & $18.39 \%$ \\
\hline & Cronbach's Alpha by factors & 0.71 & 0.65 \\
\hline
\end{tabular}

(r) Reverse items 
The Intrinsic Motivator Factor (IMF) and Extrinsic Motivation Factor (EMF) were obtained by adding each score of the coefficient matrix and multiplying by the corresponding variable presented in table 2. The construct Motivational Orientation (MO) derived from the formula Extrinsic Motivation Factor minus Intrinsic Motivation Factor (MO = EMF - IMF) and the sample was divided as shown in figure 1.

Thus, the instrument ranges between +24 as maximum value for EM and -24 as maximum value for IM. Individuals with a negative factor $(\mathrm{MO}<0)$ are intrinsically motivated. Accordingly, individuals with a positive factor $(\mathrm{MO}>0)$ are extrinsically motivated.

\section{Figure 1}

Factors for the motivational orientation construct: Intrinsic Motivation (IM) and Extrinsic Motivation (EM)

\begin{tabular}{|ccc|}
\hline IM Neutral & EM \\
& & \\
$(-)$ & 1 & $(+)$ \\
\hline
\end{tabular}

The EFA conducted for the LOMS grouped the items into three factors as shown in table 3 , and accounted for $48.27 \%$ of the total variance: $18.91 \%$ corresponded to the Budget factor, $15.50 \%$ to Motivator factor and $13.86 \%$ to Evil factor. Concerning the fourth factor in the original construct, Equity, three items were excluded due to low communality. These results are in line with findings from previous studies by Luna-Arocas and Tang (1998), in which the Equity factor has a low reliability index. The brief version of the scale applied by Tang (1995) also included three factors: Success, Budget and Evil. Each of these indicates different attitudes towards money. Factor 1, named Budget, comprised four items about money management. Factor 2, Motivator, is made up of four items that define money as an element of personal success and a motivational force. Factor 3, Evil, is made up of four items that define money as an element that generates negative changes in those who possess it. 
Table 3

Grouping of the LOMS items after EFA

\begin{tabular}{|c|c|c|c|c|}
\hline \multirow{2}{*}{\multicolumn{2}{|c|}{ Variables }} & \multicolumn{3}{|c|}{ Factors } \\
\hline & & Budget & Motivator & $\begin{array}{c}\text { Evil } \\
\text { monev }\end{array}$ \\
\hline $\begin{array}{l}1 . \\
2 . \\
3 . \\
4 . \\
5 . \\
6 . \\
7 . \\
8 . \\
9 . \\
10 . \\
11 . \\
12 .\end{array}$ & $\begin{array}{l}\text { I organize my money very well. } \\
\text { I spend my money very carefully. } \\
\text { I pay my expenses by the deadline to avoid } \\
\text { interest and fines. } \\
\text { I make plans for my financial future. } \\
\text { Money is a symbol of success. } \\
\text { Money represents personal achievements. } \\
\text { Money is motivation. } \\
\text { I am motivated to work hard for the money. } \\
\text { Money corrupts people's ethics. } \\
\text { People act without ethics to maximize their } \\
\text { financial gains. } \\
\text { Money is evil. } \\
\text { The love of money is the root of evil. }\end{array}$ & $\begin{array}{l}0.866 \\
0.861 \\
0.733 \\
0.444\end{array}$ & $\begin{array}{l}0.694 \\
0.690 \\
0.579 \\
0.568\end{array}$ & $\begin{array}{l}0.735 \\
0.709 \\
0.494 \\
0.474\end{array}$ \\
\hline & $\begin{array}{l}\text { Variance explained by factors } \\
\text { Cronbach's Alpha by factors }\end{array}$ & $\begin{array}{l}18.91 \% \\
0.737\end{array}$ & $\begin{array}{l}15.50 \% \\
0.669\end{array}$ & $\begin{array}{l}13.86 \% \\
0.647\end{array}$ \\
\hline
\end{tabular}

The reliability of the Budget, Motivator and Evil scales resulting from the EFA was tested using Cronbach's alpha, obtaining 0.737 for Budget, 0.669 for Motivator and 0.647 for Evil. The items "The work that requires low skills and little responsibility should pay lower wages", "People doing the same job should be paid according to performance" and "People who are doing the same work must be paid in the same way", referring to the Equity factor in the original construct, were excluded due to low communality (cutoff value 0.400 ).

\section{Correlations}

Pearson's correlation coefficient was used to assess the relations between motivational orientation factors and attitudes towards money. Relations between the LOMS factors and the WPI factors are weak but significant, as shown on table 4 . It appears that extrinsic motivation correlates positively with Budget and, more strongly, with Motivator (0.441), and correlates negatively with Evil (-0.273). On the contrary, extrinsic motivation correlates positively with Evil (0.249). 
Table 4

Correlations between WPI and LOMS factors ${ }^{\mathrm{a}}$

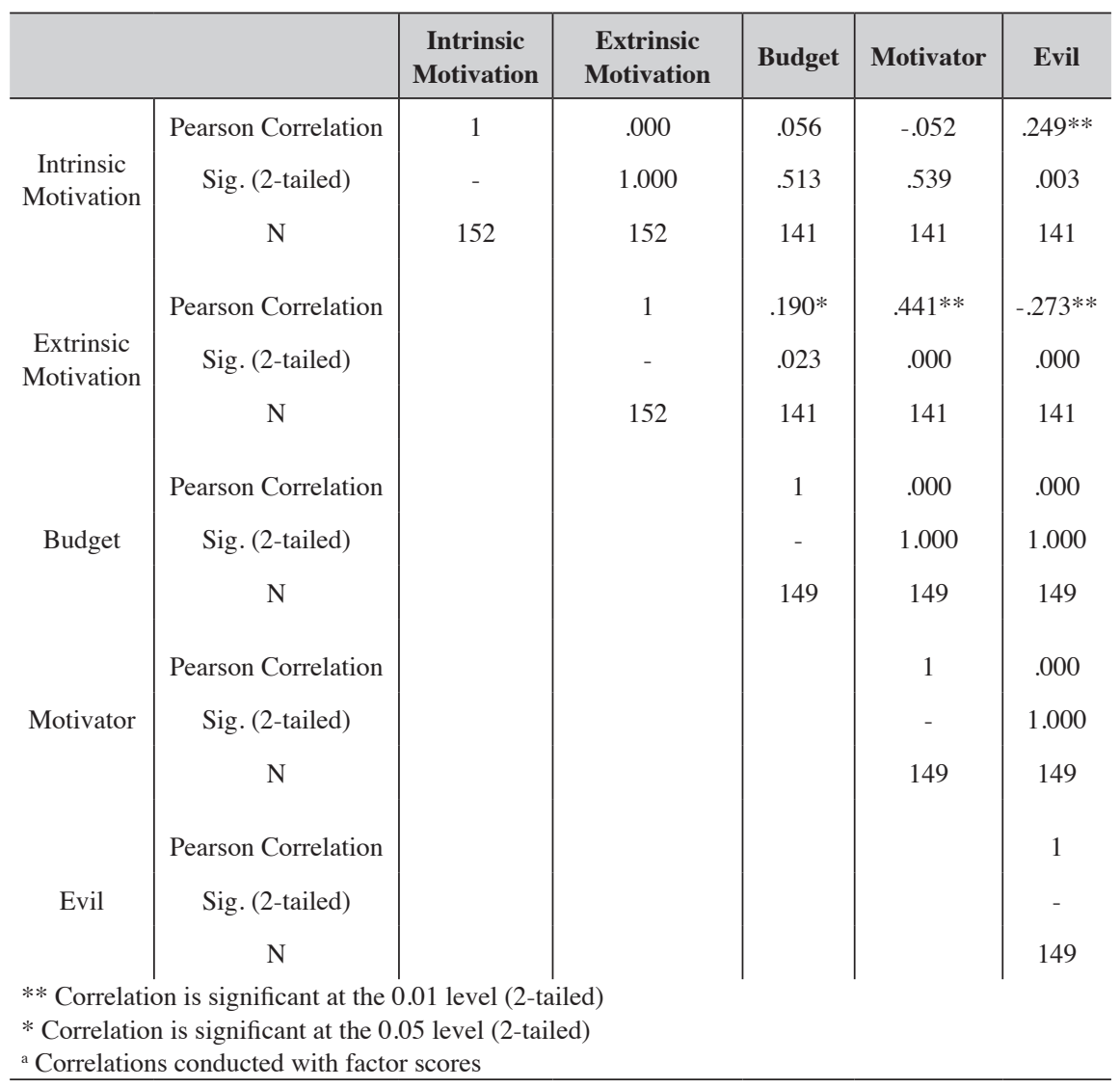

\section{Cluster analysis}

A cluster analysis was conducted based on the factor scores identified for both scales, in order to recognize profiles based on the relationship between attitudes towards money and motivational orientation. Using the three factors resulting from the LOMS and the MO construct, a cluster analysis was conducted following the Two Step Cluster method. The results allowed classifying individuals into two clusters, according to table 5 . 
Table 5

Profile clusters on money and motivational orientation

\begin{tabular}{|c|c|c|c|c|c|c|}
\hline Cluster & Label & Size & \multicolumn{4}{|c|}{ Input predictor (importance) } \\
\hline 1 & PRO MONEY & $36.9 \%(52)$ & $\begin{array}{c}\text { Motivational } \\
\text { Orientation } \\
1.28\end{array}$ & $\begin{array}{c}\text { Evil } \\
-0.69\end{array}$ & $\begin{array}{c}\text { Motivator } \\
0.41\end{array}$ & $\begin{array}{c}\text { Budget } \\
0.20\end{array}$ \\
\hline 2 & $\begin{array}{l}\text { OPPOSITE } \\
\text { MONEY }\end{array}$ & $63.1 \%(89)$ & $\begin{array}{c}\text { Motivational } \\
\text { Orientation } \\
-0.76\end{array}$ & $\begin{array}{l}\text { Evil } \\
0.45\end{array}$ & $\begin{array}{c}\text { Motivator } \\
-0.26\end{array}$ & $\begin{array}{c}\text { Budget } \\
-0.12\end{array}$ \\
\hline
\end{tabular}

Cluster 1 represents $36.9 \%$ of the sample and corresponds to individuals driven by money, who have a positive relationship with money as a Motivator (0.41) as well as with the Budget factor (0.20), and a negative relationship with the Evil factor $(-0.69)$. These individuals displayed a positive motivational orientation, that is, they are extrinsically motivated (1.28). This supports hypothesis $\mathrm{H}_{1}$.

Cluster 2 comprises $63.1 \%$ of the sample. These individuals are opposed to money, have a negative relationship with the factors Motivator (-0.26) and Budget (-0.12), and a positive relationship with money as Evil (0.45). Regarding motivation for activities, this group has a negative motivational orientation $(-0.76)$, that is, they are intrinsically motivated, thus confirming $\mathrm{H}_{2}$.

A t Test (table 6) confirms that the differences between clusters are statistically significant for all variables, except for Budget. Thus people who are driven by money differ from those who reject it in terms of motivational orientation and the perception of money both as reinforcement or reward and a source of potential unethical behavior. They do not differ in money management. 
Table 6

t Test for WPI and LOMS clusters

\begin{tabular}{|c|c|c|c|c|c|c|c|c|c|c|}
\hline & & $\begin{array}{r}\text { Leve } \\
\text { test } \\
\text { equal } \\
\text { varia }\end{array}$ & $\begin{array}{l}\text { ne's } \\
\text { for } \\
\text { ity of } \\
\text { nces }\end{array}$ & & & t-test for & Equality of & f Means & & \\
\hline & & $\mathbf{F}$ & Sig. & $\mathbf{t}$ & df & $\begin{array}{c}\text { Sig. } \\
\text { (2-tailed) }\end{array}$ & $\begin{array}{c}\text { Mean } \\
\text { Difference }\end{array}$ & $\begin{array}{l}\text { Std. Error } \\
\text { Difference }\end{array}$ & $\begin{array}{r}95 \% \text { Co } \\
\text { Interva } \\
\text { Diffe }\end{array}$ & $\begin{array}{l}\text { nfidence } \\
\text { ll of the } \\
\text { rence }\end{array}$ \\
\hline & & & & & & & & & Lower & Upper \\
\hline Motivational & (a) & 647 & .422 & 10.985 & 139 & .000 & 2.04 & 0.19 & 1.67 & 2.40 \\
\hline Orientation & (b) & & & 11.203 & 113.397 & .000 & 2.04 & 0.18 & 1.68 & 2.40 \\
\hline Budget & (a) & .100 & .753 & 1.865 & 139 & .064 & 0.33 & 0.17 & $\overline{0} \overline{02}$ & 0.67 \\
\hline & (b) & & & 1.876 & 108.676 & .063 & 0.33 & 0.17 & $0 . \overline{02}$ & 0.67 \\
\hline Motivator & (a) & .552 & .459 & 3.934 & 139 & .000 & 0.67 & 0.17 & 0.33 & 1.00 \\
\hline & (b) & & & 4.044 & 116.071 & .000 & 0.67 & 0.17 & 0.34 & 0.99 \\
\hline Evil & (a) & 249 & .618 & -7.821 & 139 & .000 & 1.15 & 0.15 & 1.43 & 0.86 \\
\hline & (b) & & & -7.772 & 104.780 & .000 & 1.15 & 0.15 & 1.44 & 0.85 \\
\hline $\begin{array}{l}\text { (a) Equal varia } \\
\text { assumed } \\
\text { (b) Equal varia } \\
\text { assumed }\end{array}$ & ces & & & & & & & & & \\
\hline
\end{tabular}

\section{Conclusions}

The study of motivation in the workplace receives considerable attention in the business and psychology literature, due to its close relationship with individual and organizational productivity (Tamayo \& Paschoal, 2003). Given the complexity of the current economic and social environment, and the need to ensure survival, organizations require consistently motivated employees to achieve their goals (Gondim \& Silva, 2004).

The assumptions of the SDT point to the existence of two types of motivational orientation, called intrinsic motivation and extrinsic motivation. As Deci and Ryan (1985) describe, intrinsic motivation refers to engaging in an activity simply for the satisfaction and pleasure of doing it, while for extrinsic motivation this engagement is a consequence of the goal to be achieved. In the present study, factor analy- 
sis of the WPI categorized two factors that match those identified by Amabile et al. (1994), intrinsic and extrinsic Motivation. However, there are some differences in the internal distribution of the items which called for the removal of some due to low theoretical consistency or low communality. This is an interesting finding given that Loo (2001) also reported the item elimination when the questionnaire is applied to a sample of business administration graduates. Similar results were obtained by Stuhlfaut (2010) in his research with young employees in advertising: while the original two factors emerge, the item distribution within each factor varies in relation to the original scale. This would suggest that the scale behaves differently in young people with little work experience. This should be addressed in future research by a confirmatory analysis, in order to develop a robust scale for this population.

Regarding the relation between money and motivation, according to Deci (1998), money as a reward is a powerful force and has a seductive quality, although it may also have different meanings for each individual (Gellerman, 1976). In this instance, the Love of Money construct (Luna \& Tang, 2004) allows assessing the meaning and importance given to money and it may provide a framework for everyday life, including in the workplace (Wong, 2008).

In order to better understand the relationship between motivation to work and attitudes towards money in young employees, it was relevant to identify profiles in those terms, thus defining the characteristics of a money-driven profile and an opposed-to-money one. The clusters allowed to further testing the hypotheses that (1) people driven by money would most likely be extrinsically motivated, and (2) people opposed to money would be intrinsically motivated.

These profiles differed clearly in relation to intrinsic/extrinsic motivation and their perceptions towards money as motivator and evil. Meanwhile, Budget is different for both groups but it is not significant. This would suggest that handling and managing money cannot be avoided, regardless of the individual's negative or positive perception of it. On the other hand, the Achieving Money Worshipper profile described by Luna and Tang (2004), which highlights the Budget factor, include people with higher income, more work experience and older. It is likely that most participants in this study, due to their age, have little work experience and may have not yet fully developed attitudes and skills for managing money properly.

Based on the expectation theory by Vroom (1970), Porter and Lawler (1988) ar- 
gue that the effort or motivation to work is a result of how attractive the reward seems and how the person perceives the relationship between effort and reward. These authors also establish the relationship between performance and rewards. In addition to its exchange value, money has a psychological, personal significance and value. From this perspective, people want to make money not only because it allows them to meet their physiological needs, but also because it provides the conditions for meeting social, self-esteem and self-actualization needs. Money is a means, not an end. In this regard, Porter and Lawler postulate that if people believe there is a direct or indirect relationship between increased salary and performance, money can be an excellent motivator. In the present research, this kind of motivation may be the foundation of Cluster 1 . Therefore, if people in this group perceive that their performance is simultaneously possible and necessary to make more money, they will perform in the best possible way.

In contrast, for people in Cluster 2, it is likely that money itself has little to no effect on their behavior and performance. For these individuals, once their basic needs are met, it may be more important to have other incentives such as more paid vacation days, better insurance benefits and daycare services for their children. Based on the findings by Judge et al. (2010) it may be assumed that, for Group 2, income goals based on the pursuit of power, competition or external control appear to be less gratifying and less effective than income goals based on the search for security, family support and recreation.

This study provides support to future research on the relationship between motivational orientations of young employees and their attitudes towards money. It also provides organizations with the knowledge that motivational support should vary according to the meaning given to money by the employees and the motivational orientation that they have; money can be a positive reinforcement or no reinforcement at all to execute tasks and to achieve goals.

Some studies report that increased access to money can be more satisfying for the relatively disadvantaged, for whom deprivation of basic needs is the basis of their daily experience (Crosby, 1976; Sweeney, McFarlin, \& Inderrieden, 1990; Judge et al., 2010). Therefore, the value of money and its relation to money itself as an extrinsic motivator may be more important for those at the lower end of the wage scale. This is an issue that should be addressed in future studies by comparing attitudes toward money, motivation styles and wage levels. Gender and age are variables that must also be considered in the psychology of money that were 
absent from this study. Some studies (Tang, 1994; Luna-Arocas \& Tang, 1998) have shown that older people and women tend to use money more carefully, and future research should explore whether this tendency in women remains the same in younger generations.

Also, in the future, longitudinal research should explore the causal effects of the emotional associations with money and its relation with work motivation, and if such is altered along the individual's development in the workplace and career. This is because one of the limitations of the study is that the sample considered only young workers who were also undergraduate students, which is a condition which cannot be made general to other types of employees.

Lastly, the findings from this study may provide guidance from the field of psychology to business managers, since, from the understanding of human behavior based on the theoretical perspectives of motivation and meaning of money, companies can direct their incentives and motivational programs for positive reinforcement towards superior performance.

\section{References}

Amabile, T. (1985). Motivation and creativity: Effects of motivational orientation on creative writers. Journal of Personality and Social Psychology 48: 393399

Amabile, T., K. Hill, B. Hennessey \& E. Tighe (1994). The work preference inventory assessing intrinsic and extrinsic motivational orientation. Journal of Personality and Social Psychology 66: 950-967.

Bergamini, C. (1990). Motivação: mitos, crenças e mal-entendidos. Revista de Administração de Empresas 30 (2): 23-34.

Crosby, F. (1976). A model of egoistical relative deprivation. Psychological Review 83: 95-113.

Deci, E. (1998). Por que fazemos o que fazemos: entendendo a automotivação. São Paulo: Negócio. 
\& R. Ryan (1985). Intrinsic motivation and self-determination in human behavior. New York: Plenum.

\& R. Ryan (2000). The what and the why of goal pursuits: human needs and the self-determination of behavior. Psychological Inquiry 11 (4): 227-268.

Diener, E. \& M. E. P. Seligman (2004). Beyond money: Toward an economy of well-being. Psychological Science in the Public Interest 5 (1): 1-31.

Dysvik, A. \& B. Kuvaas (2012). Intrinsic and extrinsic motivation as predictors of work effort: The moderating role of achievement goals. British Journal of Social Psychology. Doi: 10.1111/j.2044-8309.2011.02090.x.

Ebert, J. (2010). The surprisingly low motivational power of future rewards: Comparing conventional money-based measures of discounting with motivation-based measures. Organizational Behavior and Human Decision Processes 111: 91-92.

Field, A. (2009). Descobrindo a estatística usando o SPSS (2a ed.). Porto Alegre, RS, Brasil: Artmed.

Furnham, A. (1996). Attitudinal correlates and demographic predictors of monetary beliefs and behaviors. Journal of Organizational Behavior 17 (4): 375388.

Gagné, M. \& E. Deci (2005). Self-determination theory and work motivation. Journal of Organizational Behavior 26 (4): 331-362. doi:10.1002/job.322.

Gellerman, S. (1976). Motivação e produtividade. São Paulo: São Paulo.

Gondim, S. \& N. Silva (2004). Motivação no trabalho. In J. C. Zanelli, J. E. Borges-Andrade \& A. V. Bastos, Psicologia, organizações e trabalho no Brasi. Porto Alegre, RS, Brasil: Artmed: 145-176.

Guimaräes, S, \& J. Bzuneck (2002). Propriedades psicométricas de uma medida de avaliação da motivação intrínseca e extrínseca: um estudo exploratório. Psico-USF 7 (1): 1-8. 
Hair, J., W. Black, B. Babin, R. Anderson \& R. L. Tatham (2005). Multivariate data analysis. New Jersey: Prentice Hall.

Judge, T., R. Piccolo, N. Podsakoff, J. Shawd \& B. Riche (2010 )The relationship between pay and job satisfaction: A meta-analysis of the literature. Journal of Vocational Behavior 77: 157-167

Kouchakia, M., K. Smith-Crowe, A. Brief, C. Sousa (2013). Seeing green: Mere exposure to money triggers a business decision frame and unethical outcomes. Organizational Behavior and Human Decision Processes 121: 53-61.

Lea, S., \& P. Webley (2006). Money as tool, money as drug: The biological psychology of a strong incentive. Behavioural and Brain Sciences 29 (2): 161-209.

Lim, V. (2003). Money matters: an empirical investigation of money, face and Confucian work ethic. Personality and Individual Differences 35: 953-970.

Loo, R. (2001) Motivational orientations toward work: An evaluation of the Work Preference Inventory (student form). Measurement and Evaluation in Counseling and Development 33 (4): 222-233.

Luna-Arocas, R. \& T. Tang (2004). The love of money, satisfaction, and the Protestant work ethic: money profiles among university professors in the USA and Spain. Journal of Business Ethics 50: 329-354.

(1998). La psicología económica del dinero: análisis de la escala ética del dinero (M.E.S.) y la escala de actitudes hacia hacia el dinero (E.A.D.-6). Revista de Psicología del Trabajo y de las Organizaciones 14 (3): 295-313.

Maslow, A. (1970). A theory of human Motivation. In V. Vroom \& E. Deci, Management and motivation. Baltimore: Penguin Books: 27-41.

McCally, K. (2010). Self-determined: what motivates you? Rochester Review 72 (6): 19-21.

Medina, A., C. Gallegos \& P. Lara (2008). Motivación y satisfacción de los trabajadores y su influencia en la creación de valor económico en la empresa. Revista de Administración Pública 42 (6): 1213-1230. 
Moreira, A. (2002). Dinheiro no Brasil: um estudo comparativo do significado do dinheiro entre as regiões geográficas brasileiras. Estudos de Psicologia 7 (2): 379-387.

Pascual-Ezama, D., D. Prelec \& D. Dunfield (2013). Motivation, money, prestige and cheats. Journal of Economic Behavior \& Organization 93: 367-373.

Penna, A. (2001). Introdução a Motivação e a Emoção. Rio de Janeiro: Imago.

Porter, L. \& S. Lawler (1988) Teorías de Motivación. México: Edit. Prentice.

Ryan, R. \& E. Deci (2000a). Intrinsic and extrinsic motivations: classic definitions and new directions. Contemporary Educational Psychology 25 (1): 54-67.

(2000b). Self-determination theory and the facilitation of intrinsic motivation, social development, and well-being. American Psychologist 55 (1): 68-78.

Skinner, B. (1953/2003). Ciência e comportamento humano. 11th ed. São Paulo: Martins Fontes.

Stuhlfaut, W. (2010). Evaluating the Work Preference Inventory and its measurement of motivation in creative advertising professionals. Journal of Current Issues \& Research in Advertising 32: 81-93.

Sweeney, P., D. McFarlin \& E. Inderrieden (1990). Using relative deprivation theory to explain satisfaction with income and pay level: A multistudy examination. Academy of Management Journal 33: 423-436.

Tamayo, A. \& T. Paschoal (2003). A relação da motivação para o trabalho com as metas do trabalhador. Revista de Administração Contemporânea 7: 33-54.

Tang, T. (1992). The meaning of money revisited. Journal of Organizational Behavior 13 (2): 197-202.

(1993). The meaning of money: extension and exploration of the Money Ethic Scale in a sample of university students in Taiwan. Journal of Organizational Behavior 14: 93-99. 
(1995). The development of a short money ethic scale: attitudes towards money and pay satisfaction revisited. Personality and Individual Differences 19: 809-816.

(2007). Income and quality of life. Journal of Business Ethics 72: 375-393.

(2010). Money, the meaning on money, management, spirituality and religion. Journal of Management, Spirituality and Religion 7: 173-189.

, Kim, J \& D. Tang (2000). Does attitude toward money moderate the relationship between intrinsic job satisfaction and voluntary turnover? $\mathrm{Hu}$ man Relations 52 (2): 213-245.

R. Luna-Arocas, T. Sutarso (2005) From income to pay satisfaction: the love of money and pay equity comparison as mediators and culture (the United States and Spain) and gender as moderators. The Journal of the Iberoamerican Academy of Management 3 (1): 7-26.

Vroom, V. (1970). The nature of relationship between motivation and performance. In V. H. Vroom \& E. L. Deci, Management and motivation. Baltimore: Penguin Books: 229-235

Wong, H. (2008). Religiousness, love of money, and ethical attitudes of Malaysian evangelical christians in business. Journal of Business Ethics 81: 169-191. 